\title{
Breast cancer: trends in international incidence in men and women
}

\author{
E Kreiter ${ }^{1}$, A Richardson ${ }^{\star}, 2$, J Potter ${ }^{3}$ and $Y$ Yasui $^{1}$ \\ ${ }^{1}$ Department of Public Health Science, School of Public Health, University of Alberta 3-381 Edmonton Clinic Health Academy, \\ 11405 87th Avenue, Edmonton Alberta T6G 1C9, Canada; ${ }^{2}$ Wayne Francis Cancer Epidemiology Research Group, School of \\ Health Sciences, University of Canterbury, Private Bag 4800, Christchurch 8140, New Zealand and ${ }^{3}$ Public Health Sciences Division, \\ Fred Hutchinson Cancer Research Center, 1100 Fairview Avenue N, M4B402, Seattle, WA 98109, USA
}

Background: The age-standardised incidence of breast cancer varies geographically, with rates in the highest-risk countries more than five times those in the lowest-risk countries.

Methods: We investigated the correlation between male $(\mathrm{MBC})$ and female breast cancer $(\mathrm{FBC})$ incidence stratified by female age-group ( $<50$ years, and $\geqslant 50$ years) and used Poisson regression to examine male incidence rate ratios according to female incidence rates.

Results: Age-adjusted breast cancer incidence rates for males and females share a similar geographic distribution (Spearman's correlation $=0.51 ; P<0.0001$ ). A correlation with male incidence rates was found for the entire female population and for women aged 50 years and over. Breast cancer incidence rates in males aged $<50$ years were not associated with FBC incidence, whereas those in males aged $\geqslant 50$ years were. MBC incidence displays a small 'hook' similar to the Clemmesen's hook for FBC, but at a later age than the female hook.

Interpretation: Further investigation of possible explanations for these patterns is warranted. Although the incidence of breast cancer is much lower in men than in women, it may be possible to identify a cause common to both men and women.

The age-standardised incidence of breast cancer in men and women varies by country, with rates in the highest-risk countries being more than five times those in the lowest-risk countries (Curado et al, 2007). For women, it has been hypothesised that these geographic differences reflect differences in reproductive patterns such as age at menarche, age at first pregnancy, number of births, and duration of breast feeding (Beral et al, 2002; Colditz, 2005). It seems likely that reproductive factors cannot completely explain the geographic differences, however, as male breast cancer (MBC) incidence shows similar variation (Ewertz et al, 1989; Thomas, 1993; Ly et al, 2013). Dietary factors have also been suggested as an explanation for geographical differences in breast cancer incidence (Armstrong and Doll, 1975), but aside from alcohol and obesity, evidence for a role of specific nutrients or dietrelated factors in breast cancer is lacking (World Cancer Research Fund, American Institute for Cancer Research, 1997; World
Cancer Research Fund, American Institute for Cancer Research, 2007; Hartz and He, 2013; Chajes and Romieu, 2014; Norat et al, 2014), It is possible that prenatal factors, including maternal nutrition, may be associated with breast cancer (Park et al, 2008; Lillycrop and Burdge, 2014). It is highly likely that some risk factors for breast cancer remain to be identified (MacMahon, 2006; Hoover, 2012). The similar geographic variation for $\mathrm{MBC}$ and female breast cancer (FBC) suggests the possibility of a common non-reproductive aetiologic factor (or factors) for breast cancer in men and women.

Previous analyses have found similarities between male and female trends in breast cancer incidence. The incidence of MBC in Scandinavia during 1943-1982 varied over time and by country (Ewertz et al, 1989). The variation in incidence between countries was the same for MBC and FBC (with Danish males and females having the highest incidence, followed by Swedish, Norwegian, and

*Correspondence: Professor A Richardson; E-mail: ann.richardson@canterbury.ac.nz

Received 31 October 2013; revised 13 January 2014; accepted 15 January 2014; published online 11 February 2014

(c) 2014 Cancer Research UK. All rights reserved 0007-0920/14 
Finnish males and females), suggesting overlapping aetiology for $\mathrm{MBC}$ and FBC. MBC incidence increased monotonically with age in all countries (Ewertz et al, 1989). The incidence of breast cancer in US men increased by $26 \%$ during 1973-1998, a smaller increase than the $52 \%$ increase observed in women during the same time period, but the incidence in women is likely to have been affected by mammographic screening (Giordano et al, 2004). A comparison of male and female Surveillance, Epidemiology, and End Results (SEER) breast cancer data from 1976-2005 found similar breast cancer incidence trends for $\mathrm{MBC}$ and $\mathrm{FBC}$ in the United States (Anderson et al, 2010), again suggesting that there may be breast cancer risk factors common to both sexes. Recently, an international comparison showed that $\mathrm{MBC}$ and $\mathrm{FBC}$ age-adjusted incidence rates are correlated (Ly et al, 2013).

A comparison of breast cancer rates in men and women may be helpful in identifying differences and similarities and allowing the identification of common aetiological factor(s). The incidence of breast cancer in males is about $1 \%$ than in females. About $20 \%$ of men with breast cancer have a first-degree relative with breast cancer, with between 4 and $40 \%$ of breast cancers estimated to result from autosomal dominant inheritance (particularly BRCA1 and BRCA2 mutations), compared with $5-10 \%$ in women (Fentiman et al, 2006). This difference may reflect a similar estimate with greater uncertainty in males because of the much lower incidence. It has been suggested that there may be two types of breast cancer in women: an 'early-onset' type that is dependent on hormonal exposures occurring early in reproductive life, and a 'late-onset' type dependent on accumulated lifetime hormonal and/ or environmental exposures. MBC resembles the 'late-onset' type in women (Anderson et al, 2004). It is, however, also the case that there are multiple subtypes of FBC, according to receptor status (Potter et al, 1995), and also molecular differences (Perou et al, 2000).
Analyses of MBC reported to the SEER registries (Anderson et al, $2004,2006)$ found that breast cancer in males occurs later and shows higher stage, lower grade, and more oestrogen-positive $(\mathrm{ER}+)$ tumours than in females. The biology of $\mathrm{MBC}$ resembles that of postmenopausal FBC, with low-grade and hormonereceptor-positive tumours (Anderson et al, 2004, 2006).

Age-distribution patterns of breast cancer in women vary by histologic type (Yasui and Potter, 1999; Anderson et al, 2006) and by hormone-receptor status (Yasui and Potter, 1999; Anderson et al, 2004). Age-distribution patterns in men also vary by ER status (Anderson et al, 2004).

Known positive and inverse associations for $\mathrm{MBC}$ and premenopausal and postmenopausal FBC are shown in Table 1. This table provides an indication only; the true picture is further complicated by the fact that, in women, risk factors differ according to receptor status (Potter et al, 1995), and some associations found for BC in women have not been investigated in men, particularly in prospective studies, because the incidence of MBC is so much lower (Hankinson et al, 2008; Sousa et al, 2013).

Risk factors common to $\mathrm{MBC}$ and $\mathrm{FBC}$ are family history, alcohol, radiation exposure, and (for $\mathrm{MBC}$ and postmenopausal FBC) high oestrogen levels and high BMI. Our objective was to further investigate the possibility of shared aetiological factors for $\mathrm{MBC}$ and FBC. We undertook a worldwide analysis of patterns in $\mathrm{MBC}$ and $\mathrm{FBC}$ incidence, and examined whether the correlation between $\mathrm{MBC}$ and $\mathrm{FBC}$ incidence persists after stratification by age less than 50 years, and 50 years and over. It was important to do this for FBC, because risk factors differ for premenopausal and postmenopausal $\mathrm{FBC}$ and because $\mathrm{MBC}$ shares many characteristics with postmenopausal FBC. We stratified MBC by age $<50$ years and $\geqslant 50$ years because, although changes in $\mathrm{FBC}$ incidence are consistent with hormonal changes, other factors related to age

Table 1. Positive and inverse associations with premenopausal and postmenopausal female breast cancer and male breast cancer ${ }^{a}$

\begin{tabular}{|c|c|c|c|}
\hline Associations & $\begin{array}{l}\text { Premenopausal female breast } \\
\text { cancer }\end{array}$ & $\begin{array}{l}\text { Postmenopausal female breast } \\
\text { cancer }\end{array}$ & Male breast cancer \\
\hline High risk & $\begin{array}{l}\text { Family history of breast cancer } \\
\text { Late age at first birth }\end{array}$ & $\begin{array}{l}\text { Family history of breast cancer } \\
\text { Late age at first birth } \\
\text { High blood oestrogen }\end{array}$ & $\begin{array}{l}\text { Family history of breast cancer } \\
\text { Kleinfelter's syndrome } \\
\text { Testicular or liver damage } \\
\text { Oestrogen intake } \\
\text { Radiation exposure }\end{array}$ \\
\hline Moderate risk & $\begin{array}{l}\text { Height } \\
\text { Low BMI } \\
\text { Benign breast disease } \\
\text { Early menarche } \\
\text { Current/recent OC use } \\
\text { Cowden syndrome } \\
\text { Alcohol } \\
\text { Radiation exposure } \\
\text { Birth weight }\end{array}$ & $\begin{array}{l}\text { Height } \\
\text { High BMI } \\
\text { Benign breast disease } \\
\text { Early menarche } \\
\text { Late menopause } \\
\text { Current/recent HRT use } \\
\text { Obesity } \\
\text { Alcohol } \\
\text { Radiation exposure } \\
\text { Type II diabetes } \\
\text { In-utero diethylstilboestrol }\end{array}$ & $\begin{array}{l}\text { Cowden syndrome } \\
\text { Occupational exposure (heat) } \\
\text { High BMI } \\
\text { Obesity }\end{array}$ \\
\hline Suspected risk & $\begin{array}{l}\text { Low vitamin D intake } \\
\text { High blood IGF-1 }\end{array}$ & $\begin{array}{l}\text { High blood prolactin } \\
\text { Birth order }\end{array}$ & $\begin{array}{l}\text { Occupational exposure (exhaust emissions, magnetic } \\
\text { fields) } \\
\text { Alcohol } \\
\text { Birth order }\end{array}$ \\
\hline Inverse associations & $\begin{array}{l}\text { Childhood overweight } \\
\text { Parity } \\
\text { Extended breast feeding } \\
\text { Tamoxifen }\end{array}$ & $\begin{array}{l}\text { Childhood overweight } \\
\text { Parity } \\
\text { Extended breast feeding } \\
\text { Tamoxifen } \\
\text { Physical activity }\end{array}$ & Physical activity \\
\hline
\end{tabular}


may influence changes in incidence. If so, similar changes may be observed in $\mathrm{MBC}$ incidence. We also examined breast cancer incidence rate ratios (IRRs) for males and females, comparing the incidence rate for each male 5-year age group to the incidence rate among 40- to 44-year-old males, and the incidence rate for each female 5-year age group to the incidence rate among females aged $40-44$ years.

\section{MATERIALS AND METHODS}

We analysed 104 populations where the male population contributed at least 5 million person-years during 1998-2002 (Curado et al, 2007). We used the male population size as the inclusion criterion for our analysis to ensure that we obtained stable estimates of $\mathrm{MBC}$ rates; estimates of $\mathrm{FBC}$ rates are far more stable than those of MBC because FBC is much more common. Some 'geographically defined populations' were stratified by ethnic group. In those cases, each ethnic group of the 'geographically defined population' was regarded as a population (the 104 populations included 98 'geographically defined populations'). Table 2 provides a list of the 104 populations, with the number of male person-years in each population.

We calculated the age-adjusted incidence rates of breast cancer for both males and females (using direct standardisation) and compared them for each population. We used the World Standard Population, using the standard 18 -year age groups (Ahmad et al, 2001). We also investigated the correlation between MBC and FBC stratified by female age group $(<50$ years and $\geqslant 50$ years).

We performed a Poisson regression of MBC using random effects. We grouped the populations by the age-adjusted female incidence rates: five groups of $<40,40-59,60-79,80-99$, and $\geqslant 100$ per 100,000 woman-years. We then fitted a Poisson model of the count of breast cancer in each age category for males with an offset of the log person years for males, adjusting for age. We used the 5-group indicator (the female age-adjusted incidence rates) as the only covariate and each population as a random effect (a model without random effects was a poorer fit than the random-effects model). This model yields the MBC IRR for each group of the 5 -group indicator, compared with the reference group $(<40$ per 100000 woman-years). We removed males $<20$ years from the analysis, as the incidence rate of breast cancer in those age categories is close to zero.

Last, we examined breast cancer IRRs for males and females, comparing the incidence rate for each male 5-year age group to the incidence rate among 40- to 44-year-old males, and the incidence rate for each female 5-year age group to the incidence rate among females aged $40-44$ years.

\section{RESULTS}

$\mathrm{MBC}$ incidence is correlated with $\mathrm{FBC}$ incidence worldwide. In countries where the age-standardised incidence of $\mathrm{FBC}$ is high, the age-standardised incidence of MBC is also high (Figure 1).

Because $\mathrm{MBC}$ is thought to be similar to postmenopausal $\mathrm{FBC}$, we stratified the female populations into females aged $<50$ years and females $\geqslant 50$ years, and compared the age-adjusted breast cancer incidence rates for the two stratified populations to the total male age-adjusted breast cancer incidence rate for each population. The correlation between the MBC and FBC incidence rates was the same whether we included the entire female population or restricted the analysis to women aged $<50$ years (Spearman correlation $=0.49 ; \quad P<0.0001)$ or women $\geqslant 50$ years $(0.50$; $P<0.0001)$.
When we modelled the association between $\mathrm{MBC}$ and $\mathrm{FBC}$ incidence, the rate ratios for $\mathrm{MBC}$ incidence in countries with the highest FBC incidence rates were twice as high (after age adjustment) as in countries with the lowest FBC incidence rates. Calculation of an IRR for males, stratified by male age $<50$ years and $\geqslant 50$ years showed no correlation between male IRR and female incidence rates for males aged $<50$ years (Figure 2 ), but a statistically significant correlation for males aged $\geqslant 50$ years, with the rate ratios for $\mathrm{MBC}$ incidence in countries with the highest $\mathrm{FBC}$ incidence rates being twice as high as in countries with the lowest FBC incidence rates (Figure 3). Similarly (data not shown), the IRR for males aged $<50$ years was not correlated with the incidence rates for females aged $<50$ years, but the IRR for males aged $\geqslant 50$ years was correlated with the incidence rates for females aged $\geqslant 50$ years. Conversely, the IRR for all males was correlated with both the incidence rates for females aged $<50$ years and for females aged $\geqslant 50$ years (similar to the Spearman correlation results reported above).

We compared IRRs for males and females, comparing the incidence rate for each male 5-year age group to the incidence rate for 40- to 44-year-old males, and the incidence rate for each female 5-year age group to the incidence rate for females aged 40-44 years. Male IRRs are greater than female IRRs, and display a small 'hook' similar to the Clemmesen's hook for FBC (Figure 4). However, the male hook appears to occur at a later age $(\sim 60$ years) than the female hook.

\section{DISCUSSION}

Our findings confirm the recent report that $\mathrm{MBC}$ incidence is correlated with FBC incidence worldwide (Ly et al, 2013). In countries where the age-standardised incidence of FBC is high, the age-standardised incidence of $\mathrm{MBC}$ is also high. Although the correlation (Spearman correlation coefficient: $0.51, P<0.0001$ ) was moderate, it shows that $25 \%$ of the variation in $\mathrm{MBC}$ can be explained by variation in FBC. Previously it had been suggested that the geographic variation in breast cancer incidence is due to differences between countries in known risk factors, especially reproductive factors (Beral et al, 2002; Colditz, 2005), but the correlation reported here between worldwide $\mathrm{MBC}$ and $\mathrm{FBC}$ incidence rates supports the hypothesis that known reproductive risk factors cannot completely explain the geographic variation in breast cancer incidence (MacMahon, 2006; Hoover, 2012).

The correlation between $\mathrm{MBC}$ and $\mathrm{FBC}$ incidence is present for $\mathrm{MBC}$ and $\mathrm{BC}$ in women aged $<50$ years, and between $\mathrm{MBC}$ and $B C$ in women aged $\geqslant 50$ years. Thus, the correlation did not vary by female age-group (as a proxy for premenopausal and postmenopausal breast cancer). This suggests the possibility of a common aetiologic factor (or factors) for breast cancer in men and women irrespective of menopausal status.

When we modelled the association between $\mathrm{MBC}$ and $\mathrm{FBC}$ incidence, the rate ratios for $\mathrm{MBC}$ incidence in countries with the highest FBC incidence rates were twice as high (after age adjustment) as in countries with the lowest FBC incidence rates. The association between MBC IRRs and FBC incidence rates varied with male age ( $<50$ years and $\geqslant 50$ years); $B C$ rates in males aged $<50$ years were not associated with $\mathrm{FBC}$ incidence, whereas those in males aged $\geqslant 50$ years were associated with $\mathrm{FBC}$ incidence.

It is possible that the correlation between $\mathrm{BC}$ in males aged $\geqslant 50$ years and FBC (both total FBC and FBC in those aged $\geqslant 50$ years) is related to hormone-receptor status, because older men, as well as women, are more likely to have hormone-receptor-positive cancers. In a US population-based study of breast cancer during 1973-1998, men were statistically significantly more likely to have $\mathrm{ER}+/$ progesterone receptor-positive $(\mathrm{PR}+) \mathrm{BC}$ than women. Over $90 \%$ of men had ER + tumours, and $81 \%$ had $\mathrm{PR}+$ 


\begin{tabular}{|c|c|}
\hline Brazil, Sao Paulo (1998-2002) & 24820634 \\
\hline Costa Rica (1998-2002) & 9972584 \\
\hline Canada, Alberta (1998-2002) & 7597155 \\
\hline Canada, British Columbia (1998-2002) & 10081204 \\
\hline Canada, Ontario (1998-2002) & 28910687 \\
\hline USA, Alabama: White (1998-2002) & 7868931 \\
\hline USA, Arizona (1998-2002) & 12884245 \\
\hline USA, California: Asian and Pacific Islander (1998-2002) & 10091588 \\
\hline USA, California: Black (1998-2002) & 6185706 \\
\hline USA, California: Hispanic White (1998-2002) & 26812333 \\
\hline USA, California: non-Hispanic White (1998-2002) & 40508432 \\
\hline $\begin{array}{l}\text { USA, California, Greater San Francisco Bay Area: non-Hispanic } \\
\text { White (1998-2002) }\end{array}$ & 8024193 \\
\hline $\begin{array}{l}\text { USA, California, Los Angeles County: Hispanic White } \\
\text { (1998-2002) }\end{array}$ & 10262489 \\
\hline $\begin{array}{l}\text { USA, California, Los Angeles County: non-Hispanic White } \\
(1998-2002)\end{array}$ & 7682666 \\
\hline USA, Colorado (1998-2002) & 10870681 \\
\hline USA, Connecticut: White (1998-2002) & 7175648 \\
\hline USA, Florida: Black (1998-2002) & 6009715 \\
\hline USA, Florida: White (1998-2002) & 32291874 \\
\hline USA, Georgia: Black (1998-2002) & 5652359 \\
\hline USA, Georgia: White (1998-2002) & 14010547 \\
\hline USA, Georgia, Atlanta (1998-2002) & 7185494 \\
\hline USA, Illinois: White (1998-2002) & 24662209 \\
\hline USA, Indiana (1998-2002) & 14917711 \\
\hline USA, lowa (1998-2002) & 7167835 \\
\hline USA, Kentucky (1998-2002) & 9877898 \\
\hline USA, Louisiana: White (1998-2002) & 7130305 \\
\hline USA, Massachusetts (1998-2002) & 15315553 \\
\hline USA, Michigan: White (1998-2002) & 20255042 \\
\hline USA, Michigan, Detroit: White (1998-2002) & 7089924 \\
\hline USA, Missouri: White (1998-2002) & 11836459 \\
\hline USA, NPCR: Black (1998-2002) & 67113198 \\
\hline USA, NPCR: White (1998-2002) & 452119975 \\
\hline USA, New Jersey: White (1998-2002) & 16169919 \\
\hline USA, New York State: Black (1998-2002) & 6769984 \\
\hline USA, New York State: White (1998-2002) & 36028895 \\
\hline USA, Ohio: White (1998-2002) & 23920372 \\
\hline USA, Oklahoma (1998-2002) & 8482218 \\
\hline USA, Oregon (1998-2002) & 8514153 \\
\hline USA, Pennsylvania: White (1998-2002) & 25963236 \\
\hline USA, SEER (9 Registries): Black (1998-2002) & 7731566 \\
\hline USA, SEER (9 Registries): White (1998-2002) & 50989670 \\
\hline USA, South Carolina: White (1998-2002) & 6784715 \\
\hline USA, Texas: Black (1998-2002) & 6025121 \\
\hline USA, Texas: White (1998-2002) & 44033895 \\
\hline USA, Utah (1998-2002) & 5619190 \\
\hline USA, Washington, Seattle (1998-2002) & 10113742 \\
\hline USA, Wisconsin (1998-2002) & 13258499 \\
\hline China, Guangzhou City (2000-2002) & 5589593 \\
\hline China, Hong Kong (1998-2002) & 16352700 \\
\hline China, Shanghai (1998-2002) & 15914368 \\
\hline
\end{tabular}

\section{Table 2. (Continued)}

India, Chennai (Madras) (1998-2002)

India, New Delhi (1998-2002)

India, Mumbai (Bombay) (1998-2002)

India, Nagpur (1998-2002)

India, Poona (1998-2002)

Israel: Jews (1998-2002)

Japan, Miyagi Prefecture (1998-2002)

Japan, Osaka Prefecture (1998-2002)

Korea, Busan (1998-2002)

Korea, Daegu (1998-2002)

Korea, Incheon (1998-2002)

Korea, Seoul (1998-2002)

Malaysia, Sarawak (1998-2002)

Philippines, Manila (1998-2002)

Singapore: Chinese (1998-2002)

Turkey, Izmir (1998-2002)

Austria (1998-2002)

Belarus (1998-2002)

Belgium, Flanders (1998-2001)

Bulgaria (1998-2002)

Croatia (1998-2002)

Czech Republic (1998-2002)

Denmark (1998-2002)

Finland (1998-2002)

Germany, Brandenburg (1998-2002)

Germany, Free State of Saxony (1998-2002)

Germany, Munich (1998-2002)

Germany, Northrhine-Westphalia: Munster (1998-2002)

Ireland (1998-2002)

Italy, North East Cancer Surveillance Network (1998-2002)

Latvia (1998-2002)

Lithuania (1998-2002)

Norway (1998-2002)

Portugal, Porto (1998-2002)

Portugal, South Regional (1999-2001)

Russia, St Petersburg (1998-2002)

Serbia (1999-2002)

Slovak Republic (1998-2002)

Sweden (1998-2002)

The Netherlands (1998-2002)

UK, East of England Region (1998-2002)

UK, England, Merseyside and Cheshire (1998-2002)

UK, England, North Western (1998-2002)

UK, England, Northern and Yorkshire (1998-2002)

UK, England, Oxford Region (1998-2002)

UK, England, South and Western Regions (1998-2002)

UK, England, Thames (1998-2002)

UK, England, Trent (1998-2002)

UK, England, West Midlands (1998-2002)

UK, Scotland (1998-2002)

Australia, New South Wales (1998-2002)

Australia, Queensland (1998-2002)

Australia, Victoria (1998-2002)

New Zealand (1998-2002)
11017202

34383610

32678581

5222436

9341935

12121210

5790926

21520295

9496570

6367113

6400210

24717750

5265380

12991010

6235690

8420512

19402182

23503799

11718854

19676019

10679500

24953178

13189753

12650851

6391741

10749078

5694350

6370497

9439864

5098417

5495497

8228924

11146041

7694390

6434783

10521466

10682378

13128455

21956316

39398982

6727978

5676126

10070643

15941287

6733800

16297153

33619900

11740169

12943866

12172990

16105962

8923441

11774167

9476550 


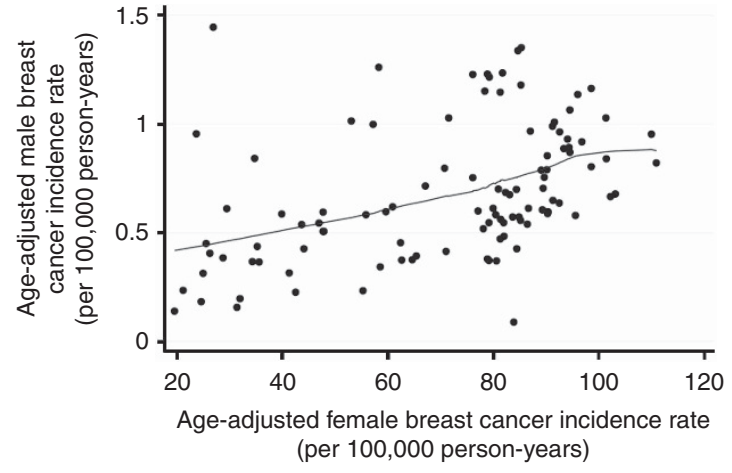

Figure 1. Male and female age-adjusted breast cancer rates by population. Spearman's correlation $=0.51 ; P<0.0001$.

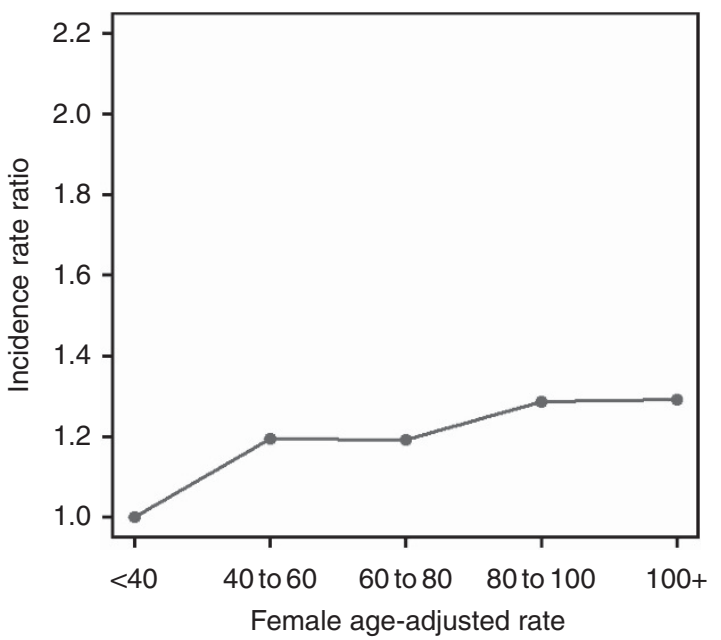

Figure 2. Incidence rate ratios for male breast cancer (under 50 years) in relation to female breast cancer incidence per 100000 woman-years.

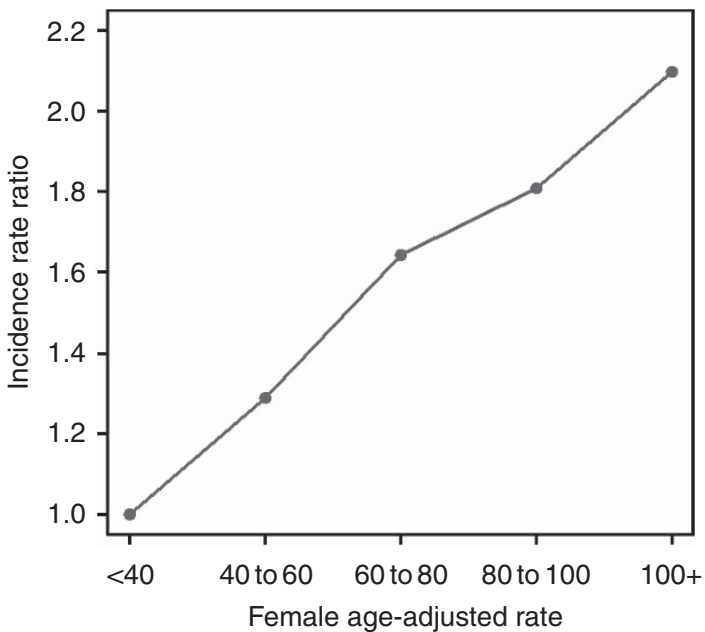

Figure 3. Incidence rate ratios for male breast cancer $(50+$ years $)$ in relation to female breast cancer incidence per 100000 woman-years.

tumours, with the proportion of ER + tumours increasing with increasing age. Whether hormone-receptor status changed over time was not reported (Giordano et al, 2004). Male hormonereceptor status more closely resembled that in women aged $\geqslant 50$ years than in younger women, but the proportion with receptorpositive tumours $(\mathrm{ER}+/ \mathrm{PR}+, \mathrm{ER}+/ \mathrm{PR}-$, or $\mathrm{ER}-/ \mathrm{PR}+)$ was even higher among men than among postmenopausal women: in

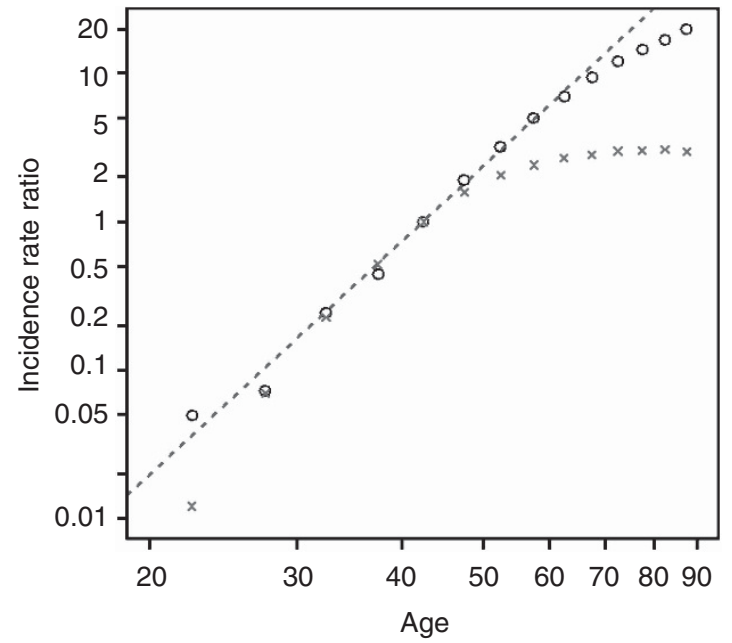

Figure 4. Male and female breast cancer incidence rate ratios by age. Male o o o o, Female $x \times x$.

men, $78 \%$ of tumours were $\mathrm{ER}+/ \mathrm{PR}+$, whereas in women aged $\geqslant 50$ years, $65 \%$ were $\mathrm{ER}+/ \mathrm{PR}+$, and in women under 50 years, $57 \%$ were $\mathrm{ER}+/ \mathrm{PR}+$ (Anderson et al, 2004). In a more recent US population-based comparison, $92.4 \%$ of breast cancers in men were $\mathrm{ER}+$ compared with $77.5 \%$ in women. The incidence of ER +1 $\mathrm{PR}+$ and $\mathrm{ER}+/ \mathrm{PR}-\mathrm{BC}$ in females continued to rise after age 50 years, in contrast to the incidence of $\mathrm{ER}-/ \mathrm{PR}-$ and $\mathrm{ER}-/ \mathrm{PR}+$ BC. Patterns in men could not be determined because of small numbers in some groups (Anderson et al, 2010).

It is also possible that $\mathrm{BC}$ in men $<50$ years is predominantly the result of genetic predisposition (Ottini et al, 2010). This may explain the lack of an association between BC in young males (where a higher proportion will be the result of genetic predisposition) and overall $\mathrm{BC}$ in females, whereas $\mathrm{BC}$ in older males and females may share a greater proportion of environmental or non-genetic endogenous risk factors. Migrant studies suggest that environmental risk factors contribute to geographic differences in FBC incidence (Hoover, 2012). The patterns we report here may be consistent with an early-stage exposure common to $\mathrm{MBC}$ and $\mathrm{FBC}$, with promoter(s) (such as oestrogen) acting later having a greater impact on $\mathrm{FBC}$ than on $\mathrm{MBC}$.

A third possibility is that the difference between Figures 2 and 3, showing that $\mathrm{BC}$ rates in males aged $<50$ years were not associated with FBC incidence, whereas those in males aged $\geqslant 50$ years were associated, is due to the small number of men aged $<50$ years diagnosed with BC. However, it is important to note that we restricted our analyses to populations that included a male population contributing at least 5 million person-years during 1998-2002 to obtain stable estimates of MBC incidence rates.

Breast cancer incidence rates increase with age in both males and females. In women, the rate of increase decelerates sharply around age 50 years (a phenomenon known as 'Clemmesen's hook'). An analysis of BC incidence trends in SEER data for men and women from 1976 to 2005 found that age-specific incidence rates among women increased rapidly until age 50 years, paused, and then rose more slowly (Clemmesen's hook; Anderson et al, 2010) but this and an earlier study of MBC incidence failed to show a 'Clemmesen's hook' (Ewertz et al, 1989; Anderson et al, 2010).

In women, the shape of the age-incidence curve may be related to histologic type (Anderson et al, 2006) and to hormone receptor status. An analysis of FBC in Denmark (Yasui and Potter, 1999) found that female ER and progesterone receptor (PR)-positive $(\mathrm{ER}+/ \mathrm{PR}+)$ breast cancer increased continuously with age, with a sudden decrease in the rate of increase around age 44 years. The incidence of $\mathrm{ER}+/ \mathrm{PR}$ - increased slightly during the menopausal 
period but only slightly thereafter. The incidence of $\mathrm{ER}-/ \mathrm{PR}+$ breast cancer increased to about age 43 years then decreased subsequently. The incidence of $\mathrm{ER}-/ \mathrm{PR}-$ increased with age to about age 50 years, and then remained unchanged.

The shape of the age-incidence curve for $\mathrm{BC}$ also varies with the underlying incidence (with different shapes in low-, moderate-, and high-incidence countries) but, in Iceland, rates were seen to transition across these shapes over the period 1911-1972; this was interpreted as a cohort effect (Bjarnason et al, 1974). Our finding may be the result of a similar cohort effect in MBC incidence leading to the emergence of a male 'Clemmesen's hook', however, few countries have had a statistically significant increase in recent MBC incidence rates (but the confidence intervals for estimated annual percentage change in $\mathrm{MBC}$ incidence were wide, reflecting the small number of MBC cases each year in most countries; Ly et al, 2013).

The decline in FBC has been attributed to a decline in oestrogen levels associated with menopause, but Yasui and Potter (1999) previously noted the likelihood that the female decline in incidence is due not exactly to the pre- to post-menopausal breast cancer transition but rather to the way in which the hormone-receptordefined subtypes change with age. Males do not exhibit a decline in hormone production, but sex hormone-binding globulin rises with age in males whereas in females, it remains flat (Khosla et al, 1998), and neither androgen nor ERs are strongly associated with MBC incidence or survival (Pich et al, 1999; Kidwai et al, 2004). This suggests the possibility of a non-hormonal risk factor that affects both male and female incidence rates and their changes with age similarly.

This was a descriptive study, and therefore limited in its ability to demonstrate causal associations. However, the correlation we found between $\mathrm{MBC}$ and $\mathrm{FBC}$ incidence rates (Spearman's correlation coefficient $0.51, P<0.0001$ ) is strong enough to suggest that there is an association between geographic distribution and $\mathrm{BC}$ in both men and women. This association is consistent with regional comparisons in Scandinavia and in the United States, and in a recent international comparison (Ewertz et al, 1989; Anderson et al, 2010; Ly et al, 2013). We have also found a correlation between male and female incidence rates for the entire female population and for women aged 50 years and over. Breast cancer IRRs in males aged $<50$ years were not associated with FBC incidence, whereas those in males aged $\geqslant 50$ years were associated. Male IRRs are greater than female, and display a small 'hook' similar to the Clemmesen's hook for FBC, but the male hook appears to occur at a later age than the female hook. We have provided biologically plausible explanations for these patterns. The specificity of the association for older males, but not younger males, may support a causal association between geographically distributed environmental risk factors and MBC and FBC.

Further investigation of possible explanations for these patterns is warranted, including further analyses of $\mathrm{MBC}$ and $\mathrm{FBC}$ incidence by country, taking into account differences between countries in some known risk factors such as BMI and parity. Although the incidence of $\mathrm{BC}$ is much lower in men than in women, it may be possible to identify a cause that is common to both men and women, which may be relevant to prevention in both sexes.

\section{ACKNOWLEDGEMENTS}

The Wayne Francis Charitable Trust provides support for the Wayne Francis Cancer Epidemiology Research Group, University of Canterbury, New Zealand.

\section{CONFLICT OF INTEREST}

The authors declare no conflict of interest.

\section{REFERENCES}

Ahmad OB, Boschi-Pinto C, Lopez AD, Murray CJL, Lozano R, Inouye M (2001) Age standardization of rates: a new WHO standard. GPE Discussion Paper Series. World Health Organization: Geneva.

Anderson WF, Althuis MD, Brinton LA, Devesa SS (2004) Is male breast cancer similar or different than female breast cancer? Breast Cancer Res Treat 83(1): 77-86.

Anderson WF, Jatoi I, Tse J, Rosenberg PS (2010) Male breast cancer: a population-based comparison with female breast cancer. J Clin Oncol 28(2): 232-239.

Anderson WF, Pfeiffer RM, Dores GM, Sherman ME (2006) Comparison of age distribution patterns for different histopathologic types of breast carcinoma. Cancer Epidemiol Biomarkers Prev 15(10): 1899-1905.

Armstrong B, Doll R (1975) Environmental factors and cancer incidence and mortality in different countries, with special reference to dietary practices. Int J Cancer 15(4): 617-631.

Beral V, Bull D, Doll R, Peto R, Reeves G, La Vecchia C, Magnusson C, Miller T, Peterson B, Pike M, Thomas D, van Leeuwen F. Cancer CGoHFiB (2002) Breast cancer and breastfeeding: collaborative reanalysis of individual data from 47 epidemiological studies in 30 countries, including 50302 women with breast cancer and 96973 women without the disease. Lancet 360(9328): 187-195.

Bjarnason O, Day N, Snaedal G, Tulinius H (1974) Effect of Year of Birth on Breast-Cancer Age-Incidence Curve in Iceland. Int J Cancer 13(5): 689-696.

Chajes V, Romieu I (2014) Nutrition and breast cancer. Maturitas 77(1): 7-11. Colditz GA (2005) Epidemiology and prevention of breast cancer. Cancer Epidemiol Biomarkers Prev 14(4): 768-772.

Curado MP, Edwards B, Shin HR, Storm H, Ferlay J, Heanue M, Boyles P (2007) Cancer Incidence in Five Continents. Vol. 9. Lyon: IARC.

Ewertz M, Holmberg L, Karjalainen S, Tretli S, Adami HO (1989) Incidence of male breast cancer in Scandinavia, 1943-1982. Int J Cancer 43(1): 27-31.

Fentiman IS, Fourquet A, Hortobagyi GN (2006) Male breast cancer. Lancet 367(9510): 595-604.

Giordano SH, Cohen DS, Buzdar AU, Perkins G, Hortobagyi GN (2004) Breast carcinoma in men: a population-based study. Cancer 101(1): 51-57.

Hankinson S, Tamimi R, Hunter D (2008) Breast Cancer. Oxford: OUP.

Hartz AJ, He T (2013) Cohort study of risk factors for breast cancer in post menopausal women. Epidemiol Health 35: e2013003.

Hoover RN (2012) That recognised risk factors can explain past and present international differences in breast cancer incidence: misconceptions 5 . Br J Cancer 107(3): 408-410.

Khosla S, Melton 3rd LJ, Atkinson EJ, O’Fallon WM, Klee GG, Riggs BL (1998) Relationship of serum sex steroid levels and bone turnover markers with bone mineral density in men and women: a key role for bioavailable estrogen. J Clin Endocrinol Metab 83(7): 2266-2274.

Kidwai N, Gong Y, Sun X, Deshpande CG, Yeldandi AV, Rao MS, Badve S (2004) Expression of androgen receptor and prostate-specific antigen in male breast carcinoma. Breast Cancer Res 6(1): R18-R23.

Lillycrop KA, Burdge GC (2014) Breast cancer and the importance of early life nutrition. Cancer Treat Res 159: 269-285.

Ly D, Forman D, Ferlay J, Brinton LA, Cook MB (2013) An international comparison of male and female breast cancer incidence rates. Int $J$ Cancer 132(8): 1918-1926.

MacMahon B (2006) Epidemiology and the causes of breast cancer. Int J Cancer 118(10): 2373-2378.

Michels KB, Trichopoulos D, Robins JM, Rosner BA, Manson JE, Hunter DJ, Colditz GA, Hankinson SE, Speizer FE, Willett WC (1996) Birthweight as a risk factor for breast cancer. Lancet 348(9041): 1542-1546.

Norat T, Aune D, Chan D, Romaguera D (2014) Fruits and vegetables: updating the epidemiologic evidence for the WCRF/AICR lifestyle recommendations for cancer prevention. Cancer Treat Res 159: 35-50.

Ottini L, Palli D, Rizzo S, Federico M, Bazan V, Russo A (2010) Male breast cancer. Crit Rev Oncol Hematol 73(2): 141-155.

Park SK, Kang D, McGlynn KA, Garcia-Closas M, Kim Y, Yoo KY, Brinton LA (2008) Intrauterine environments and breast cancer risk: meta-analysis and systematic review. Breast Cancer Res 10(1): R8.

Perou CM, Sorlie T, Eisen MB, van de Rijn M, Jeffrey SS, Rees CA, Pollack JR, Ross DT, Johnsen H, Akslen LA, Fluge O, Pergamenschikov A, Williams C, Zhu SX, Lonning PE, Borresen-Dale AL, Brown PO, Botstein D (2000) Molecular portraits of human breast tumours. Nature 406(6797): 747-752. 
Pich A, Margaria E, Chiusa L, Candelaresi G, Dal Canton O (1999) Androgen receptor expression in male breast carcinoma: lack of clinicopathological association. Br J Cancer 79(5-6): 959-964.

Potter JD, Cerhan JR, Sellers TA, McGovern PG, Drinkard C, Kushi LR, Folsom AR (1995) Progesterone and estrogen receptors and mammary neoplasia in the Iowa Women's Health Study: how many kinds of breast cancer are there? Cancer Epidemiol Biomarkers Prev 4(4): 319-326.

Ruddy KJ, Winer EP (2013) Male breast cancer: risk factors, biology, diagnosis, treatment, and survivorship. Ann Oncol 24(6): 1434-1443.

Sousa B, Moser E, Cardoso F (2013) An update on male breast cancer and future directions for research and treatment. Eur J Pharmacol 717(1-3): $71-83$.

Thomas DB (1993) Breast cancer in men. Epidemiol Rev 15(1): 220-231.
World Cancer Research Fund, American Institute for Cancer Research (1997) Food, Nutrition and the Prevention of Cancer: a Global Perspective. American Institute for Cancer Research: Washington DC.

World Cancer Research Fund, American Institute for Cancer Research (2007) Food, Nutrition, Physical Activity, and the Prevention of Cancer: a Global Perspective. World Cancer Research Fund, American Institute for Cancer Research: Washington DC.

Yasui Y, Potter JD (1999) The shape of age-incidence curves of female breast cancer by hormone-receptor status. Cancer Causes Control 10(5): 431-437.

This work is published under the standard license to publish agreement. After 12 months the work will become freely available and the license terms will switch to a Creative Commons AttributionNonCommercial-Share Alike 3.0 Unported License. 